\title{
“I am a Rhetoric Physics Student-Teacher": Identity Construction of an Indonesian Physics Student-Teacher
}

\author{
Endang Purwaningsih ${ }^{1 *}$, Ahmad Suryadi ${ }^{1}$, Nuril Munfaridah ${ }^{1,2}$ \\ ${ }^{1}$ Universitas Negeri Malang, INDONESIA \\ 2 University of Groningen, THE NETHERLANDS
}

Received 27 March 2020 - Accepted 13 October 2020

\begin{abstract}
The concept of teacher identity plays an important role in improving teacher professionalism. However, most studies related to teacher identity in Indonesia are still rarely disclosed, especially the identity of physics teachers. Through a case study design, we aim to explore the identity of a student-teacher in the context of the Indonesian physics teacher preparation program. The participant was a fourth-year student, Syahrul (pseudonym), who was taking an internship program. Data were collected through semi-structured interviews, learning observations, field notes, and document analysis, such as teacher syllabus, lesson plans, and students' worksheets. The results of this study reveal multi-layered perspectives of a physics student-teacher identity. We conclude that Syahrul's identity was constructed through rhetoric skills obtained from his involvement in student co-curricular activities such as involvement in a student organization formed by the university. Implications on physics teacher preparation programs are also discussed.
\end{abstract}

Keywords: physics education, rhetoric skills, teacher identity, teacher professional development

\section{INTRODUCTION}

The initial phase as a science teacher has been considered a difficult phase for the career stage as a science teacher (Luft \& Patterson, 2002). The lack of knowledge in their respective disciplines and educational knowledge in curriculum, instruction, and assessment is presumed as one of the factors of that situation. Meanwhile, Luft (2007) strongly suggested raising research based on beginning science teachers to provide an evidence-based foundation to design an effective professional development for science teachers. Studying teacher identity as a process can be the starting point of the changes in teacher professional development as well as teacher preparation programs (Avraamidou, 2014b). Therefore, one attempt that can be done in the context of this research-based is the investigation of how the science teachers at the beginning stage develop their identity as science teachers. As a matter of fact, several studies have been conducted to find out how this identity was constructed by novice teachers - teachers with teaching experience under three years (Losano et al., 2018; Ro, 2019), experienced teachers - teachers with teaching experience more than three years (Bukor, 2015; Marco-Bujosa et al., 2018; Martin, 2019), even student-teachers (Çetin \& Eren, 2019; Chen \& Mensah, 2018; Chong et al., 2011; Deng et al., 2018; Gracia et al., 2019; Gross \& Hochberg, 2016; Leeferink et al., 2019; van Lankveld et al., 2016). It shows how the teacher identity develops through the career stage of becoming a physics teacher.

Teacher identity grows continuously recently. As a result, one of the factors in student-teacher identity development is the activity of teaching practices during the internship program. Through this program, the student-teachers have a chance to develop pedagogyrelated activities carried out at school context, including conversations with people in the school environment and relationships with teaching colleagues (Trent, 2012). Several studies have been carried out to uncover how students-teachers construct their teacher identity. For instance, Avraamidou (2014a) found that the identity of a novice science teacher began to develop at the

(c) 2020 by the authors; licensee Modestum. This article is an open access article distributed under the terms and conditions of the Creative Commons Attribution License (http://creativecommons.org/licenses/by/4.0/). 


\section{Contribution to the literature}

- Recently, the teacher professional identity has received a lot of attention among researchers in the education field. Only a small fraction of studies focuses on the identity of physics teachers. Therefore, this study elucidates the exploration of how the identity of a physics student-teacher is formed.

- This study implies the importance of activities outside the classroom by analyzing one student-teacher identity that is very active in campus organizations.

- This study highlights the need to rethink university curricula in integrating curriculum content into the development of the physics teacher's identity.

university and continued to evolve in post-graduation circumstances. Teacher identity also developed in the process of internship programs (Hong, 2010; Wei et al., 2019). In addition, Zhao and Zhang (2017) explained that teacher identity tends to improve after teaching practice. Nonetheless, these studies focused on high-achieving student-teachers whose, in general, the academic repertoire is not questioned.

In addition, it is also important for teacher educators to construe how student-teachers build their identity as professional teachers (Beauchamp \& Thomas, 2009; Naidoo, 2017). It catalyzes directly in student-teachers in their future teacher professional identity. Research related to professional identity has been conducted in many countries such as the U.S. (Badia \& Iglesias, 2019; Deneroff, 2016; El Nagdi et al., 2018; Maddamsetti, 2020; Schaefer, 2013), Australia (Martin, 2019), Chile (Darragh \& Radovic, 2019), the Netherlands (Leeferink et al., 2019), Korea (Ro, 2019), Turkey (Çetin \& Eren, 2019), China (Deng et al., 2018; Teng, 2019; Wei et al., 2019; Ye \& Zhao, 2019), Spain (Gracia et al., 2019; Losano et al., 2018), Brazil (Dominguez et al., 2015), Iran (MahmoudiGahrouei et al., 2016), Hongkong (Trent, 2016), Singapore (Chong et al., 2011), Taiwan (Chien, 2019), Malaysia (Tangen et al., 2017), and Indonesia (Ilfiandra et al., 2019). However, there are a few amounts of studies on teacher professional identity in Indonesian science teachers. Most of the studies on teacher professional identity in Indonesia have been done in the context of teacher and pre-service teacher language education (Astuti, 2016; Gandana \& Parr, 2013; Hidayati, 2018; Mambu, 2017; Manara, 2013; Widodo, 2017; Wirza, 2018).

This study is aimed to address gaps that have been found in the literature. Considering that identity is fluid and tends to change over time through teachers' experiences (Lutovac \& Kaasila, 2018), we maintain to use an identity framework to capture how the physics student-teachers conceptualize themselves as a preservice physics teacher. We contend that this exploration is an essential part of developing teacher professionalism. This study is conducted with a different participant's characteristics, deviating from what most literature conveyed, which used to involve students such as an excellent academic background. We argue that it is important to conduct an inquiry in such participants since there are many students with below-average competence in reality. A unique case employing Syahrul (a pseudonym), one male student-teacher majoring in physics education with below-average academic competence, is presented through this study. Specifically, the research question in this study is as follows:

- How does Syahrul develop his identity as a physics teacher through his life experience and the internship program that considered as the beginning stage as a physics teacher?

In responding to the research question, we aim to provide an overview of the context of physics studentteachers in the early stage as a physics teacher, especially in the context of Indonesian student-teachers. As a result, we can understand how the initial phase of the physics teacher's identity is evolving. This knowledge can be valuable for physics educators, professional development experts, faculty members, and policymakers.

\section{THEORETICAL FRAMEWORK}

\section{The Conceptualization of Identity}

"I feel wrong when choosing my department at the university." The term "wrong department" is very often heard in various universities, including in physics majors. Physics education students sometimes consider themselves unable to teach physics content in as much they feel they are not born as a physics teacher. We can say that most students do not have teacher identity at the first stage when they start university education. We can then reflect on the question: "what kind of students is actually referred to as a physics student-teacher?" This question can lead us to the concept of one's identity, where understanding how people see themselves and how they are seen or recognized by others becomes a special interest (Avraamidou, 2019a). This identity is formed in the socio-cultural context (Avraamidou, $2019 b$ ) through one's experience and relationships with others and the environment. This identity will then also help someone in making decisions and determining goals (Izadinia, 2013).

Identity is fundamental to develop teacher professionalism (Izadinia, 2014; Zhao \& Zhang, 2017). 
According to Gee (2000), identity is a certain kind of person based on his internal state and his performance in society at a given time and place. Moreover, Gee (2000) conceptualized one's identity as follows: (a) nature identity - an identity that is a condition carried since a person is born; (b) discourse identity - the identity of individual characters recognized by others through dialogues; (c) affinity identity - an experience shared in various communities or groups, and (d) institutional identity - the position of someone who is recognized in an institution. Identity is fluid and continues to evolve over time (Lutovac \& Kaasila, 2018). In addition, identity is also a complex variable (Hanna et al., 2019). One of the sub-studies of identity is the teacher's professionalism identity. Although there is no clear definition, Beijaard et al. (2004) found that most researchers defined professional identity as a process of continuous integration of professional and personal aspects into a unified whole as a teacher. Meanwhile, specifically in the development of student-teachers' professional identity, the representation of student-teachers' identity is a manifestation of the cognitive knowledge, selfawareness, self-confidence, voice, sense of agency, and relationships with colleagues, students and parents, previous experiences, and learning communities framed in the educational context (Izadinia, 2013).

\section{A Literature Review in the Teacher Identity Development}

Wang and Du (2014) conducted a qualitative study to explore how immigrant Chinese teachers' professional identity and beliefs about the teacher-student relationship in an intercultural context. The researchers used a socio-cultural perspective to understand teachers' professional identity and an ethnographic interview. The interview addressed the questions about educational and professional experiences, beliefs, and perspectives on being a teacher in China and Denmark, and the perception of the relationship between student and teacher in both countries. The interviews were taperecorded and fully transcribed. Data were analyzed by creating subheadings and categories under each question. Some descriptive themes appeared during the analysis. In order to provide validity, the researchers discussed the main categories with the participants through email. The findings showed that prior experiences related to various cultural elements, such as ethnicity and educational background, among others, influenced the teachers' perceptions of their professional identities are influenced. Meanwhile, these identities are not fixed and continued changing over time. The interaction of student-teacher in the classroom plays a role in shifting professional teacher identities. In addition, the teachers faced challenges and dilemmas when working in the intercultural context. Considering that this study is focused on teachers' perceptions, the researchers suggested continuing the investigation through non-participant observations in the classroom so that student-teacher interaction can be observed directly.

Another study related to the investigation of professional teachers' identity is a study by Zhang et al. (2018). The study involved four participants from a regular university in southern China. This study used a two-dimensional identity framework, consisting of professional commitment and perception of the teacher's role. These two components have been confirmed as a significant role to construct student-teacher identity. Data were collected through three phases interview. All the interview results were transcribed then read iteratively. By using thematic coding, they found that student-teacher identities shifted during the practicum. The student-teacher identities rely very heavily on two dimensions: strong professional commitment and balanced role perception. This condition can only be gained with the positive influences from the current professional context and prior experiences of the student-teachers. They also illustrated that the early requirements of teacher education and parental pressure were two factors that might partly explain the low entrylevel teaching commitment of a student-teacher.

In particular, Izadinia (2016) investigated the identity of student-teachers who were enrolled in teaching practicum programs in Western Australian. There were eight participants involved, five from music discipline and three from drama discipline. This study aimed to understand the effect of the practicum program and the relation between mentor and student-teacher in constructing student-teacher identity. She used a semistructured interview because she believed that examining teacher identity change could be captured by elaborating student-teachers' voice. This study revealed that the role of the mentor positively influenced the student-teacher identity. The student-teachers were very satisfied with the feedback given by the mentor. Another finding of this study was that the positive relationship between student-teacher and mentor boosted the development of teacher identity of student-teacher through the encouragement of confidence. The support of the mentor provides an opportunity to think deeply about future careers and build visions as a professional teacher. Given that the findings showed how important the role of mentor in the development of teacher identity, the study has some implications as follows (a) the mentor needs to provide emotional and motivational support during the practicum program deliberately; (b) student-teacher needs to provide mentoring program; and (c) teacher education program needs to consider the recruitment of the mentor who passionate about their job and mentoring roles.

Deng et al. (2018) also conducted a study of studentteacher identity formation during teaching practicum. They used emotion and dilemma perspective to capture the student-teacher identity. Six participants were 
involved with the nuance discipline (i.e., English, Chinese, and Mathematics). The study used three kinds of data collection method: in-depth interviews, emotional journals, and practicum reflections. The authors analyzed the data through the coding process of the participant's emotional shifts from the beginning, the middle, and the end of the teaching activities. The authors also corroborated the results by involving the participants' reflections. The result of the study showed that, as the early stage of teacher identity construction, student-teacher identity evolved along with their emotional growth during their internship. In addition, after doing a reflection on their emotional experience, student-teachers gained more perception of teachers' responsibilities and roles. Meanwhile, this study suggested observing the class when the student-teacher was teaching. The observation can be used to triangulate the data for the study.

Wei et al. (2019) conducted a case study to explore how the beginning science teacher deals with practical work in the physics classroom. The researcher viewed teacher identity consisting of three dimensions: personal, social, and situational. They also connected this analytical framework to the operations of personal, interpersonal, and institutional factors, which influence the construction of the teacher identity. The participant in this study was an excellent student who graduated with strong preparation in physics and pedagogy from a teacher education program in western China. He was considered as the student who had successful teaching experience in an internship program. Data were collected through the observation of classroom lessons, the lesson plan, which related to practical work in 10 months. There is pre- and post-class interviews to clarify the expectation of participant in practical work. In addition, three semi-structured interviews were conducted in the beginning, middle, and end of this study. Data were analyzed through narrative format and coding from multiple sources. The findings of the study revealed that participant's professional identity could be explained into four categories as follows: (a) personal characteristics, (b) sense of agency, (c) constraints of the school context, and (d) the ongoing process of interpretation and reinterpretation of experiences with practical work. On the other hand, this study implied further investigation in this knowledge-based research, such as identifying specific activities in teacher preparation that support teachers in developing science teacher identity for teaching with practical work.

Leeferink et al. (2019) investigated the professional identity theme of ten student-teachers in universities of applied sciences in the Netherlands after experiencing workplace learning. The participants represented seven disciplines: Pedagogy, Hospitality, Social skills, English, Geography, Welfare and health care, and the economy. There were no participants with a science education background. The researchers used digital logs and in- depth interviews to capture each participant's story, which relies heavily on self-reflection. The study revealed that the workplace made an identity theme to each participant specifically. This study also addressed the workplace learning process as continuous and discontinuous. Five participants were categorized as continuous when the workplace learning connected to previous knowledge and experience of student-teachers. Meanwhile, other participants categorized as discontinuous when the workplace affects friction between professional and personal of student-teachers. These results were obtained through a thematic analysis of the stories provided by the participants. However, this study suggested continuing further explanation of the methodological aspect. The researchers suggested using multi-method triangulation and multi-data collection, for example, observing the participants' activities.

Summing up from the literature above, the studentteachers' identity was constructed by several factors, and it was also continually formed. The factors of identity construction were strongly related to the participants' characteristics, and the focus of the study represented more efforts in investigating the factors that affect student-teacher identity. The experience that studentteachers has during the preparation program of becoming a teacher plays an important role in developing their professional identities. Most of the studies about professional identities presented above were conducted in the context of non-science teachers and not in the context of Indonesia. Considering that there are many science teacher preparation programs in Indonesia, we contend that research on the science student-teacher identity construction is prominent, especially in Indonesia's student-teacher context. Another gap found in the literature is that most studies also focused on student-teachers' voices through singlesource data, such as an interview. Therefore, the study that not only focused on using interview data as the main data source is needed. The interview data could be corroborated by using another data collection method. In order to address the gaps in the literature, the present study uses multi-method triangulation by observing student-teacher teaching activity in an internship program, and it is conducted in the context of Indonesia.

\section{RESEARCH METHODOLOGY}

\section{General Background}

In studying the construction of a student-teacher identity, we employed a qualitative case study design which can be used to describe and analyze a system in depth (Merriam \& Tisdell, 2015). In general, there is very little research that employs this design, especially in the Indonesian science teacher identity context. We contend that the development of teacher identity is complex, so we maintain to focus on one physics student-teacher. Employing a single case study, we investigated a 
phenomenon that relates to one physics student-teacher identity. We analyzed the development of the science teaching identity of the participant. This single case study allows us to explore the unique conditions of an individual, such as what we presented in this study. It also allows in-depth data analysis so that it can provide complete information to a complex system. However, as a single case study, the results are limited to generalization. Still, we can enrich the knowledge-based research on science teacher identity and making transfers by providing the details of the context, the nature of the activities that occur, and the characteristics of participants to the reader (Wei et al., 2019).

\section{Context}

The study was conducted at the physics teacher preparation program of one of the public universities in Indonesia. The Indonesian government, through the Ministry of Education (MoE), conceived educational higher educations that focus on preparing prospective professional teachers, namely, Teacher Training Institute (TTI) (Faisal \& Martin, 2019). There are 421 universities classified as TTI (Kementerian Riset, Teknologi, dan Pendidikan Tinggi Republik Indonesia, 2015). When becoming a participant, Syahrul was studying in his fourth year and was carrying out an internship program in one of the public high schools in Malang, Indonesia. The internship was carried out for approximately six weeks. It aimed to provide experience teaching students in the classroom's real situation and become a way to implement previously learned content and pedagogical knowledge.

\section{Participant}

The participant in this study was a fourth-year student-teacher named Syahrul (pseudonym). Syahrul is 22 years old and he is a student majoring in physics education. He participated in a teaching practice program in high school as one of the curricula in the teacher preparation program. Syahrul was chosen as a single participant because he has unique characteristics as following descriptions: (a) he has good communication skills and rhetoric in teaching, and (b) even though Syahrul is considered as a student-teacher with below-average academic competence, Syahrul is favored by his students. The rhetoric term refers to the ability to negotiate when questions arise (Elsner, 2014). The rhetoric could influence or entertain people. This preliminary information was obtained from the mentor teacher and Syahrul's colleagues.

\section{Instruments}

This study used a multiple instrument forms as follows: four interview guides, field notes, learning observation sheets, and a video documentation rubric. The first interview guide was about the participant's belief and perceptions about teaching and learning physics. The questions are as follows: (a) How the teacher's role should be in learning physics? (b) What should be the role of students in physics class? (c) How should physics material (e.g., fluid) be taught to students? (d) Do you believe that your students would carry out physics investigations with minimal help from you? Why? (e) How you plan your instruction design?

The second set of interviews was about the participant learning experience in the past. Several questions were prompt to the participant, and some of the main questions were as follows: (a) How was your interest in learning about physics in high school? (b) Can you describe your learning experience in high school? (c) Can you describe your learning experience at the university? (d) How your past learning experiences affect the way you teach?

The third interview was conducted to investigate the participant's activity when he was doing the internship program. In this step, we confirmed a participant's answer in the first and the second session of interviews. The third interview set was as follows: (a) Can you explain how you designed the learning process for your internship program? (b) How is your relationship with your peers in the internship program? (c) How is your relationship with the mentor in the internship program? and (d) How is your relationship with your advisor?

The fourth set of interviews, which were carried out after participants out of the program, focused on the participant's feeling after joining the internship program. We also confirmed some participant's statements in the past interview. We then also conducted interviews with the participant's mentor and the participant's friends. Both participant's mentor and two participant's friends were involved in this study to observe Syahrul teaching processes.

The second instrument used in this current study was field notes. During the internship program, the participant's activity was observed and written on field notes. All participant's documents, such as lesson plans and student activity sheets, were documented. The last instrument used to investigate the identity construction of the participant was the video observation rubric. We used Caleon et al. (2018) rubric to identify the learning process during the internship program carefully. In detail, this rubric can help identify teaching strategies that teachers do. This rubric contains guidelines for identifying the lecturing process, discussion strategy, hands-on activity, and learning administration.

In order to validate the instruments used in this study, we discussed the instruments with an expert. She is currently a senior lecturer in the physics education program. Her research interest is in teacher professional development, including pedagogical content knowledge and teacher identity. She has presented her research in national and international conferences and published 
papers in several journals in this field. In addition, the instruments were also presented, discussed, and reviewed by 15 students who enrolled in the physics education graduate program. This effort is based on the assertion from Merriam and Tisdell (2015) that one strategy to improve the reliability of qualitative studies is to have discussions with colleagues.

\section{Data Collection and Analysis}

Data were collected through semi-structured interviews, learning observations, field notes, and documentation through video of participants' activities in teaching. The interview was carried out four times. Three interviews were carried out when the participant was in the internship program, and one time was carried out after the participant had finished the internship. The duration of each interview was about 20 minutes. In each interview, the researcher also clarifies some of the participant responses from the previous interview. We also conducted interviews with Syahrul's mentors and colleagues to support the findings. All interviews were conducted in Indonesian. As the first step of data analysis, we transcribed the interviews from the audio recordings into verbatim. For the second step, we coded the text through a priori coding techniques into four categories of identity (Gee, 2000), as follows: (a) nature identity, (b) discourse identity, (c) affinity identity, and (d) institution identity. Gee's identity framework gives a detailed structure method to examine teacher identity, which can be applied when interpreting interview data. The learning process carried out by Syahrul was recorded and then analyzed. Learning observation video results were analyzed using a constructivism learning observation protocol (Caleon et al., 2018). The video was then analyzed by splitting the video into multiple segments where each segment was rendered into five minutes. We were helped by other student-teachers in observing the participant's teaching style and how the students' activities in the classroom were performed. The results of the video analysis were used as the source in determining the factual practices carried out by the participant in order to clarify and support the interview data. Data from interviews and observations were also triangulated with field notes and participant documents such as syllabus and lesson plans to generate the themes. To establish the trustworthiness of data analysis, we used triangulation strategies through the following descriptions: (a) we collected the data from the various resources (e.g., different interviews, messages) for the same purpose; (b) we asked the participant to crosscheck the information that we had from the interview, and (c) we shared the data interpretation to check whether we had the same perception or not with the participant.

\section{RESULTS AND DISCUSSION}

\section{Discourse Identity: Emphasizing the Importance of Student Center Learning}

This section explains Syahrul's identity based on the perspective of discourse identity. Through this perspective, Syahrul was understood as a physics student-teacher who was currently enacting an internship in teaching practice. Discourse identity is also related to who Syahrul is, according to the people around him. This perspective presents his learning orientation, beliefs, and teaching practices. Syahrul's belief was very dominant in the constructivist realm. He believes that learning physics should be done with a student-centered inquiry. Syahrul also firmly believes that demonstrating the application of the physics concepts in everyday life is beneficial as the instruction in teaching and learning physics. This belief of inquiry learning is one aspect of a reform-oriented approach (Avraamidou, 2014a) so that it gives a chance for Syahrul to be a reform-oriented science teacher in the future. Syahrul strongly emphasized the importance of the student-center learning approach. Syahrul shared that:

\begin{abstract}
Nowadays, it is a good time to apply a student-centered approach, so students must be more active. The teacher is only a mediator. Especially in physics, students have received their physics concepts in their home. We could discuss the student's findings in class. A teacher is not just the center of learning, but the teacher is also more as a motivator for students. ... thus, it is important to be aware of how the teacher manages students to be more active in learning. (Interview 1)
\end{abstract}

In addition, the data analysis showed that inquiry learning was central to Syahrul's teaching identity. For example, in the lesson plan, which consisted of five meetings, he planned all the learning processes involving a scientific approach through group investigation. In general, the learning process is as following descriptions: (a) students in groups observe video problems at several meetings such as video breaking eggs in water (the concept of hydrostatic pressure), submarine videos (Archimedes law), and videos of the use of hydraulic jacks (Pascal's law); (b) students then collect data both through literature review and experiments and (c) students are asked to present the results of the experiment and discuss in the classroom.

Some of Syahrul's friends who also teach in the same school shared information that Syahrul taught well. For instance, he made students comfortable in learning. The expression below was Syahrul friends' response when we asked a question related to their opinions about the Syahrul teaching style. 
Syahrul's teaching and learning activities are good. He brings good atmosphere and adjusts the condition in his class. (Interview with Syahrul's friend)

From the excerpt above, we can know that Syahrul managed the classroom well. He could create a good learning environment. We also found evidence from learning observation when Syahrul tried to encourage students to propose their idea. He facilitated students with worksheets that lead students to find concepts and argue related to physical phenomena presented at the beginning of the learning process. However, video segment analysis showed that Syahrul tended to dominate and failed in the enactment of students in inquiry learning. Syahrul had difficulty in applying inquiry learning and guiding students to find concepts through worksheets. Based on the analysis of learning observation videos, Syahrul attempted to conduct inquiry learning as follows.

\section{Students are divided into groups of 4-5 people per group. Students watch videos of how submarines can sink, hover, and float. Students explain this phenomenon by searching for information from various sources with pre-prepared worksheets. At the end of the lesson, two groups present the results obtained in front of the class. (Observation of the first learning)}

What we observed from the learning process, Syahrul was developing his identity as a physics student-teacher who tried to apply inquiry learning. Syahrul combined his rhetoric skills with inquiry learning. This result is in line with the assertation of Lamote and Engels (2010) that many student-teachers use and develop studentcentered learning in their way of teaching. However, the inquiry conducted by Syahrul was not yet providing optimal results. Some students seemed difficult to complete the task in the worksheets. This finding is in agreement with the study conducted by Mansour (2013) that the consistency of constructivist belief, including inquiry learning, tends to inconsistent with its practice. Although there was a tendency for Syahrul to have a reputation as a reform-oriented teacher, Syahrul often interfered with learning through his rhetorical skills. Therefore, it was difficult to conclude Syahrul's identity. This result is consistent with the findings from Izadinia's (2013) study that discourse identity is complex and difficult to determine.

\section{Nature Identity: Men in Science}

We used the nature identity's perspective, specifically gender, to describe the characteristics of Syahrul brought from birth. In Syahrul's classroom, boys were a minority in which there were 17 female students and only four male students. Although there is a stereotype that male physics teacher is better than female physics teacher, the number of female students in the education program is still higher than male students.
Personally, this stereotype could be indicated from the interview with Syahrul when we asked Syahrul to describe his experience with some female physics teachers in his previous education.

"Female teachers were fussy, sometimes not in line with what she said and what she did" (Interview 4)

We can see that Syahrul thought that male physics teachers should be better than female physic teachers. It is not only because of the natural identity of Syahrul as a boy, but it is also more to the clarity of how male teachers explain a particular physics topic. It is also related to the characteristics of a male teacher who is assertive. According to the Syahrul point of view, this result showed that male teachers are better than female teachers. On the other side, we found the evidence that Syahrul had a role model that leads him to be a physics teacher when he studied in high school. It was common in the previous decade to have more male physics teachers in senior and junior high schools. Syahrul's experiences with some male physics teachers in his previous level of education can be seen from the following excerpts. Syahrul shared that:

\section{I am amazed by the way of Mr. Y (Syahrul's high school teacher) teaches, although he dominates learning. I can understand the concepts of the application presented. I can remember the physics formula by looking back at the application of the concept that was explained before. (Interview 2)}

\section{Mr. X's (Syarul's university teacher) teaching with inquiry is very interesting. We are seen to find physics formulas slowly. (Interview 2)}

We also asked Syahrul about his general view about the suitable teacher in teaching physics according to gender.

In my opinion, both girls and boys can be good physics teachers as long as they manage the class well. There is a female physics teacher who can teach well. (Interview 4)

The excerpt above indicates that gender played a role in the development of Syahrul's identity as a studentteacher. Syahrul considers that female teachers talk too much than male teachers. On the other hand, he indicated that it should not be different between female and male physics teachers as long as they could deliver learning and manage the classroom well. He did not have a problem with the gender of a physics teacher, although he tended to favor male physics teachers. This result is supported by some previous studies, which found that a person considers gender when choosing a role model. A female student tend to be attractive to a female teacher (Avraamidou, 2014a; Brickhouse et al., 2000), and male students tend to have more interest in a male teacher (Eliasson et al., 2016). 


\section{Affinity Identity: Relationships and Focus of Attention in Learning Physics}

We used the affinity identity framework to describe the attention that dominates Syahrul's identity and its relationship with students. This attention is related to Syahrul's choice of whether to focus on himself or to students' abilities. Meanwhile, the relationship with students focuses on whether learning centralizes student learning classically or views students as individuals who need guidance (Settlage et al., 2009).

Attention. Syahrul is very concerned about the condition of his students in the classroom. The results from his observations before carrying out teaching practices helped him to identify students' characteristics. Based on interviews, after the first learning and the third teaching practice, Syahrul showed that he needed to adjust his learning and teaching process based on students' characteristics. He felt that he needed to provide more assistance to each group when the students did an investigation on a certain physics topic.

In my opinion, the students' condition in my class was less active. It might cause that my plan did not work well. This chapter will be delivered in the fourth meeting. Based on my observation before, I have to go around the groups to guide them. By doing this, I hope the students will be more engaged in the learning process, especially when I explain some parts to them (Interview 1)

Syahrul's friends also added that Syahrul's teaching style was tailored to the characteristics of the students.

He is so humble with the people around him. He also cares about people. That's why he has a good relationship with his students... His explanation seemed to be well connected with the students, especially because most students stated that they were pleased if the teacher and students became friends. (Interview with Syahrul's friend)

It is important to notice that Syahrul can create a good situation, which is no border between the teacher and students. This condition might support students to be more active like what he expected.

Relationship. The application of learning strategies in the classroom contribute to the construction of the relationship between the teacher and students. Syahrul's relationship with his teacher during high school formed his identity as a teacher. Although all Syahrul physics teachers in high school mostly used a teacher-centered approach, Syahrul found one of his teachers was inspiring in the teaching method. Therefore, Syahrul wanted to adapt his teaching method in his class. The teacher did not explain the physical formulas mathematically like other teachers in detail, but the teacher emphasized the application of physics concepts in daily life.
What I most like from a teacher in my senior high school experience was a teacher who explains physics examples in everyday life. If the teacher explains it through examples by providing the application of concepts in daily life, I can remember the formula by looking back at the application. It makes sense. Now, I try to implement that way of teaching to my students. (Interview 2)

We found another evidence about how Syahrul's relationship with people around him influence his identity; it is from his experience in the university. Physics education was not Syahrul's first choice when attending university entrance selection. His choice was a physics engineering major. At the beginning of lectures in the physics department, he merely went through the learning process, but he did not enjoy it, and he felt in the wrong direction. However, in the development of his learning process in the physics education program, he was quite comfortable following the learning in education courses rather than physics courses. One of the lecturers impressed him. The lecture taught him how to do learning with an inquiry method. According to Syahrul, the technique used by the lecturer in teaching was very good. Syahrul tried to follow his teacher teaching style when he designed his lesson plans. This intention can be viewed from the following excerpts:

\section{The lesson plan that I made follows Mr. X's (Syahrul's university teacher) way. So, the formula is still there, for example, $w=m \cdot g$ (Syahrul wrote that formula); there is still $m$ in the worksheet, while other variables are not included there. So, students need to finish that. For example, force is the multiplication of this stuff (Syahrul pointed the $m$ letter) with this stuff (Syahrul pointed the $g$ letter). Guidance still exists, but do not immediately give the solution. The blank part is still there, but there is a direction to solve it. (Interview 3)}

The relationship that also forms Syahrul's identity is his relationship with the mentor while undergoing the teaching practice. The relationship between Syahrul and his mentor teacher was not very good. According to Syahrul, a mentor teacher's existence provided less contribution on Syahrul's learning process in becoming a physics teacher. Syahrul did not get much feedback on what he was doing. This condition made him feeling less developed during the teaching experience program.

\section{I did not get any instructions from my mentor teacher. Even before that, I collected the wrong documents, it was not corrected. I realized after I collected it. ... I am not too busy there. My friend, by his mentor, was even asked to create a module. In my opinion, giving assignments to students who are doing practice as a teacher is important to help us learn about the actual practice as a teacher. (Interview 4)}

To overcome this problem, he had many discussions with his friends, both in the same school and in different 
schools. This discussion showed that his relationship with his friends played an important role in constructing Syahrul's identity.

I prepared lesson plans with my friend who practices at school X. ... Before teaching my students, I often discussed physics concepts with two of my friends who were also practicing at the same school with mel. (Interview 1 and interview 4)

The excerpts highlight the affinity's identity of Syahrul in the context of the community of other students-teachers. Syahrul finds the effort to keep his quality teaching practice well. Although he did not obtain enough feedback from his mentor teacher, he built his interaction with other students who were in the same situation as he was.

Analysis of the data above shows that the Syahrul's identity was formed from his experience. The experience of previous learning provides input that he needs to consider the students' condition. This result is in line with Lamote and Engels' (2010) study that teaching practice helps improve students' perspective on a learning process to be more realistic. It is also important to understand students' initial knowledge (Lestari \& Fauzi, 2019) in order to have a general overview of the students' abilities that can be used in planning the learning process. Andreasen et al. (2019) emphasized that a teacher's understanding of his role in the learning process supports the development of identity as a teacher. Another factor that shapes Syahrul's identity within the framework of affinity identity is its relationship with others. The teacher's role model contributes greatly to forming Syahrul's identity. This finding is in line with Moreau and Brownhill's (2017) study that a person's teaching orientation is formed from his interactions with the teacher and lecturer who taught him. In line with Syahrul's view, teaching practice should encourage students to discuss with mentors. This is important because one of the goals of dialogue in teacher preparation is to link theory and practice (Britton \& Tippins, 2015).

\section{Institution Identity: The Role of Teachers and Organizations}

The development of Syahrul's identity cannot be separated from the institutional authorities (i.e., university and schools). In this section, Syahrul's identity is viewed from the context of student organizations that have been followed. First, Syahrul's identity is influenced by his learning experience while studying in high school. Positioning as a student, he can understand physics concepts and formulas. From high school experiences, Syahrul could reflect which the best way of teaching from his teachers in high school that worked to his process of understanding physics concepts. He preferred to have the teaching strategies that involved the application of physics concepts in daily life, and it greatly influenced the way he teaches as a student-teacher. This condition can be seen from the following excerpts.

There were three teachers when I was in high school. So, every year was different. What I didn't like was the teacher, who made physics more complicated. So, what we got during two hours of learning in the classroom was generating a physics formula with confusing pictures. The application and practice questions were not taught. If there were friends who did not practice well, they would be left behind. ... (Interview 2)

One my physics teacher always described the physics formula and continued applying that formula in an everyday life context. I was trying to follow his teaching style now. (Interview 4)

Secondly, Syahrul, as a student at the university, shaped his identity as a prospective physics teacher. At the university, he interacts with various types of characters and teaching styles of lecturers. He also learned and developed his ability to teach through method and physics courses. As mentioned in the previous section, Syahrul had a role model in his teaching style from one of the teachers in the university.

Finally, his two years of experience in managing campus organizations also provided valuable experience for Syahrul's identity. Being placed in the department of public relations in students' organization structure has increased his rhetoric skills. In addition, the department that deals with outside agencies and organizations also trained his confidence in public speaking.
Actually, like this, ... I was forced to enter the organization by my senior. There was one moment that I could not forget. At that time, in a room, there were many people, and I was told to speak in front ... I didn't prepare anything, and I had to talk. I finally learned from there. Self-taught learning from the organization because I was placed as the head of public relations. The participation in this organization for two years evoked my ability to talk in front of people. I also could communicate with the company or school principals well. (Interview 2)

This excerpt provides a shred of evidence that the role of the institution in shaping Syahrul's identity. The Syahrul's involvement in the students-organization makes him more confident to talk in front of the people, which is a teacher's needs. From the side of the kind of activities provided by the institution, Syahrul's identity was formed by formal and informal institutions. Formal institutions were schools and universities which form Syahrul's teaching style as a physics teacher. On the other hand, the campus organization formed Syahrul's identity to have high confidence in communication and rhetoric skills. As reported from previous research, 


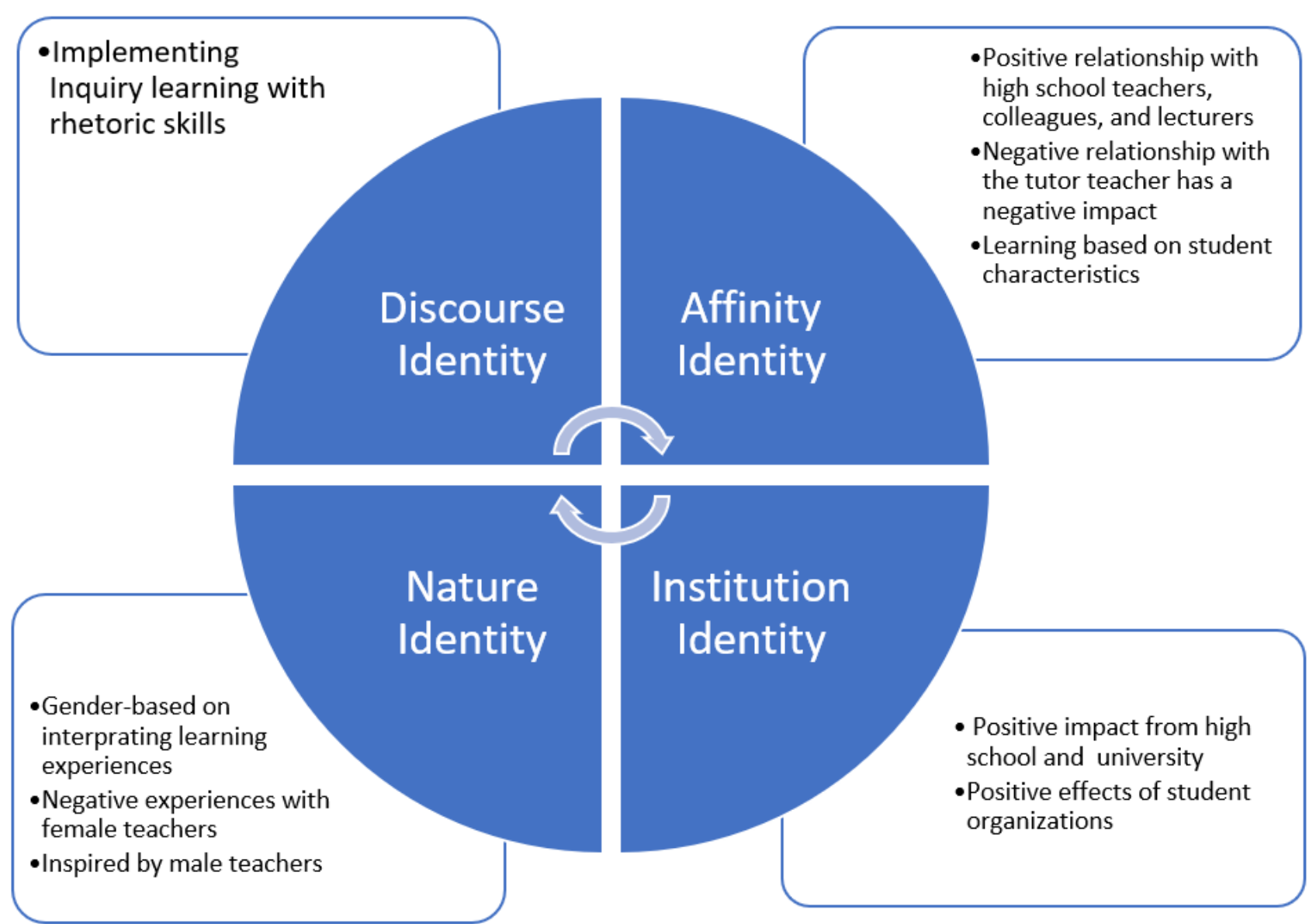

Figure 1. The construction of Syahrul's identity

informal learning experience can contribute to the development of one's identity (Close et al., 2016; Wulff et al., 2018). It supports the development of competence's belief and motivation in a science career. By this, stakeholders and policymakers need to consider the involvement of both formal and informal activities in preparing prospective physics teachers. This result is supported by findings from Andreasen et al. (2019) that university collaboration predicts the development of teacher identity.

\section{IMPLICATIONS}

The aim of this study described the teacher professional identity of a student during teaching practice in a school in the form of internship program. This description is discussed in four components of identity, namely: nature identity, discourse identity, affinity identity, and institution identity, which are presented in Figure 1. From Syahrul's case, it is showed that identity is a complex and growing over time. The identity of Syahrul's teacher professionalism builds on his experience from being a student to becoming a student-teacher. Environmental factors such as interactions with friends, campus organizations, lecturers, and mentors also support the development of Syahrul's identity. Nevertheless, Syahrul's identity as a student-teacher is still immature. For example, his belief in inquiry learning is still difficult to be applied in learning practices-besides, the mentor support when learning practices is not so optimal. Syahrul was not given sufficient feedback from his mentor during the internship program. Even so, he still believes that learning physics should present the application of physics concepts in everyday life to the students.

Syahrul builds his identity as a teacher who facilitates students' inquiry. This strategy was a reformative thought and very different from the traditional learning he had felt at school. Syahrul has reformative thoughts on the learning outcomes obtained while he was a student. Therefore, universities are very dominant in developing one's teaching identity. Moreover, teaching identity would be considered as a prediction about a future career of a student-teacher (Izadinia, 2013). On the other hand, the outside classroom experience, such as involving the student's organization, can contribute quite dominantly in shaping Syahrul's identity. As a prospective professional teacher, the head of public relations in student organizations increases his confidence in communication and rhetoric skills. Syahrul builds his identity as a rhetoric communicative teacher. A study from Kerssen-Griep (2001) showed that teachers who have good communication skills have a positive influence on student's motivation. Furthermore, 
this developing motivation will improve student learning outcomes (McCroskey et al., 2006).

This study provides an overview of how studentteacher identity is formed through experience. As a drawback of this study, this study gives some implications to the teacher preparation program. First, universities need to increase collaboration with schools to cater to the student-teachers with teaching practices. Second, universities also need to ensure that students obtain maximum guidance from mentor teachers. Third, we need to pay attention to the issue where a lecturer should not focus on gender differences but needs to be fair in giving attention to all students.

The limitation of this study is the consistency of participant responses. As a student-teacher, the identity of Syahrul is not yet so mature that it needs to require good instruments. Future studies can try to use interview techniques with the help of life grid interviews or other data collection methods to maximize data exploration. In addition, this study involved one participant which we are not aimed to generalize our findings. However, this study appears as a preliminary report in looking at the development of participant identity for the next phase from one single participant. So, it will be fruitful if the next study can involve more participants and gain more various experiences during the internship program.

\section{CONCLUSION}

This case study illustrates that student-teachers identity is complex and unstable. In the perspective of nature identity, Syahrul builds his identity through positive experiences from male teachers and bad experiences from female teachers. Although Syahrul's identity in the perspective of discourse identity is immature, it shows that he is a pre-service teacher who believes in inquiry as the best approach in teaching and learning physics concepts and he implements it with rhetoric skills. From the affinity perspective, Syahrul's identity is built from his relationships with the people around him (e.g., high school teachers, university teacher, mentor teacher, and his friends) that involve his belief and influence decision in the development of becoming a physics teacher. Institution identity originating from the position of Syahrul as students from various levels has positive and negative impacts on the construction of his identity as the form as a formal learning experience. Meanwhile, Syahrul's participation in students' organization beyond the formal institution also plays an important role in shaping his teacher identity as a physics teacher.

\section{REFERENCES}

Andreasen, J. K., Bjørndal, C. R. P., \& Kovač, V. B. (2019). Being a teacher and teacher educator: The antecedents of teacher educator identity among mentor teachers. Teaching and Teacher Education, 85, 281-291. https:/ / doi.org/10.1016/j.tate.2019.05.011

Astuti, P. (2016). Practitioner of cooperative learning as part of novice teachers' professional Identity. TEFLIN Journal, 27(2), 132-153. https://doi.org/ 10.15639/teflinjournal.v27i2/132-152

Avraamidou, L. (2014a). Tracing a beginning elementary teacher's development of identity for science teaching. Journal of Teacher Education, 65(3), 223-240. https:/ / doi.org/10.1177/0022487113519476

Avraamidou, L. (2014b). Studying science teacher identity: Current insights and future research directions. Studies in Science Education, 50(2), 145179.

https:/ / doi.org/10.1080/03057267.2014.937171

Avraamidou, L. (2019a). "I am a young immigrant woman doing physics and on top of that I am Muslim": Identities, intersections, and negotiations. Journal of Research in Science Teaching, 57, 311-341. https:/ / doi.org/10.1002/tea.21593

Avraamidou, L. (2019b). Science identity as a landscape of becoming: Rethinking recognition and emotions through an intersectionality lens. Cultural Studies of Science Education, 15, 323-345. https://doi.org/ $10.1007 /$ s11422-019-09954-7

Badia, A., \& Iglesias, S. (2019). The Science Teacher Identity and the Use of Technology in the Classroom. Journal of Science Education and Technology, 28(5), 532-541. https:// doi.org/10.1007 / s10956-019-09784-w

Beauchamp, C., \& Thomas, L. (2009). Understanding teacher identity: An overview of issues in the literature and implications for teacher education. Cambridge Journal of Education, 39(2), 175-189. https:/ / doi.org/10.1080/03057640902902252

Beijaard, D., Meijer, P. C., \& Verloop, N. (2004). Reconsidering research on teachers' professional identity. Teaching and Teacher Education, 20(2), 107128. https:/ / doi.org/10.1016/j.tate.2003.07.001

Brickhouse, N. W., Lowery, P., \& Schultz, K. (2000). What kind of a girl does science? The construction of school science identities. Journal of Research in Science Teaching, 37(5), 441-458.

Britton, S. A., \& Tippins, D. J. (2015). Practice or theory: Situating science teacher preparation within a context of ecojustice philosophy. Research in Science Education, 45(3), 425-443. https:/ / doi.org/10.1007/ s11165-014-9430-1

Bukor, E. (2015). Exploring teacher identity from a holistic perspective: Reconstructing and reconnecting personal and professional selves. Teachers and Teaching, 21(3), 305-327. https:/ / doi.org/10.1080/13540602.2014.953818

Caleon, I. S., Tan, Y. S. M., \& Cho, Y. H. (2018). Does teaching experience matter? The beliefs and 
practices of beginning and experienced physics teachers. Research in Science Education, 48(1), 117149. https:/ / doi.org/10.1007/s11165-016-9562-6

Çetin, G., \& Eren, A. (2019). Turkish prospective teachers' professional goals, beliefs about the attainability of these goals, identities, and possible selves. Asia Pacific Education Review, 20(3), 423-447. https:// doi.org/10.1007/s12564-018-9561-6

Chen, J. L., \& Mensah, F. M. (2018). Teaching contexts that influence elementary preservice teachers' teacher and science teacher identity development. Journal of Science Teacher Education, 29(5), 420-439. https:// doi.org/10.1080/1046560X.2018.1469187

Chien, S.-C. (2019). Toward an understanding of high school in-service English teachers' identities in their professional development. Asia Pacific Education Review, 20(3), 391-405. https://doi.org/ 10.1007/s12564-019-09582-4

Chong, S., Low, E. L., \& Goh, K. C. (2011). Emerging professional teacher identity of pre-service teachers. Australian Journal of Teacher Education, 36, 50-64.

Close, E. W., Conn, J., \& Close, H. G. (2016). Becoming physics people: Development of integrated physics identity through the Learning Assistant experience. Physical Review Physics Education Research, 12(1), 010109. https://doi.org/10.1103/PhysRevPhys EducRes.12.010109

Darragh, L., \& Radovic, D. (2019). "To Tia with love": Chilean mathematics teacher identities after professional development. ZDM, 51(3), 517-527. https://doi.org/10.1007/s11858-018-01023-7

Deneroff, V. (2016). Professional development in person: Identity and the construction of teaching within a high school science department. Cultural Studies of Science Education, 11(2), 213-233. https://doi.org/ $10.1007 / \mathrm{s} 11422-013-9546-Z$

Deng, L., Zhu, G., Li, G., Xu, Z., Rutter, A., \& Rivera, H. (2018). Student teachers' emotions, dilemmas, and professional identity formation amid the teaching practicums. The Asia-Pacific Education Researcher, 27(6), 441-453. https://doi.org/10.1007/s40299018-0404-3

Dominguez, C. R. C., Viviani, L. M., Cazetta, V., Guridi, V. M., Faht, E. C., Pioker, F. C., \& Cubero, J. (2015). Professional choices and teacher identities in the science teacher education program at EACH/USP. Cultural Studies of Science Education, 10(4), 11891213. https:/ / doi.org/10.1007/s11422-014-9650-8

El Nagdi, M., Leammukda, F., \& Roehrig, G. (2018). Developing identities of STEM teachers at emerging STEM schools. International Journal of STEM Education, 5(36). https://doi.org/10.1186/ s40594-018-0136-1
Eliasson, N., Sørensen, H., \& Karlsson, K. G. (2016). Teacher-student interaction in contemporary science classrooms: Is participation still a question of gender? †. International Journal of Science Education, 38(10), 1655-1672. https://doi.org/ 10.1080/09500693.2016.1213457

Elsner, J. (Ed.). (2014). Art and rhetoric in Roman culture. Cambridge University Press.

Faisal, \& Martin, S. N. (2019). Science education in Indonesia: Past, present, and future. Asia-Pacific Science Education, 5(4). https://doi.org/10.1186/ s41029-019-0032-0

Gandana, I., \& Parr, G. (2013). Professional identity, curriculum and teaching Intercultural Communication: An Indonesian case study. Language, Culture and Curriculum, 26(3), 229-246. https:// doi.org/10.1080/07908318.2013.833620

Gee, J. P. (2000). Identity as an Analytic Lens for Research in Education. Review of Research in Education, 25, 91-125. https://doi.org/10.2307/ 1167322

Gracia, E. P., Rodríguez, R. S., \& Pontes Pedrajas, A. (2019). Analysis of science and technology preservice teachers' beliefs on the construction of the teachers' professional identity during the Initial training process. EURASIA Journal of Mathematics, Science and Technology Education, 15(10), em1756. https:// doi.org/10.29333/ ejmste/105896

Gross, M., \& Hochberg, N. (2016). Characteristics of place identity as part of professional identity development among pre-service teachers. Cultural Studies of Science Education, 11(4), 1243-1268. https:// doi.org/10.1007/s11422-014-9646-4

Hanna, F., Oostdam, R., Severiens, S. E., \& Zijlstra, B. J. H. (2019). Domains of teacher identity: A review of quantitative measurement instruments. Educational Research Review, 27, 15-27. https:// doi.org/10.1016 /j.edurev.2019.01.003

Hidayati, S. (2018). Exploring novice EAP teacher's selfreflection as a platform for professional development. Indonesian Journal of Applied Linguistics, 8(2), 441-451. https:// doi.org/10.17509 /ijal.v8i2.13310

Hong, J. Y. (2010). Pre-service and beginning teachers' professional identity and its relation to dropping out of the profession. Teaching and Teacher Education, 26(8), 1530-1543. https://doi.org/ $10.1016 / j$.tate.2010.06.003

Ilfiandra, I., Setiadi, R., \& Sumarto, S. (2019). The comparison of professional identity of prospective teachers between UPI Indonesia and UPSI Malaysia. Advances in Social Science, Education and Humanities Research. The 2nd International Conference on Educational Sciences (ICES 2018), 
Bandung, Indonesia. https://doi.org/10.2991/ ices-18.2019.21

Izadinia, M. (2013). A review of research on student teachers' professional identity. British Educational Research Journal, 39(4), 694-713. https://doi.org/ 10.1080/01411926.2012.679614

Izadinia, M. (2014). Teacher educators' identity: A review of literature. European Journal of Teacher Education, 37(4), 426-441. https:/ / doi.org/10.1080/ 02619768.2014 .947025

Izadinia, M. (2016). Preservice teachers' professional identity development and the role of mentor teachers. International Journal of Mentoring and Coaching in Education, 5(2), 127-143. https:/ / doi.org /10.1108/IJMCE-01-2016-0004

Kementerian Riset, Teknologi, dan Pendidikan Tinggi Republik Indonesia. (2015). https://ristekdikti.go. id/wp-content/uploads/2016/01/RAKERNASREFORMASI-LPTK.pdf

Kerssen-Griep, J. (2001). Teacher communication activities relevant to student motivation: Classroom facework and instructional communication competence. Communication Education, 50(3), 256-273. https:/ / doi.org/10.1080/ 03634520109379252

Lamote, C., \& Engels, N. (2010). The development of student teachers' professional identity. European Journal of Teacher Education, 33(1), 3-18. https:/ / doi.org/10.1080/02619760903457735

Leeferink, H., Koopman, M., Beijaard, D., \& Schellings, G., L. M. (2019). Overarching professional identity themes in student teacher workplace learning. Teachers and Teaching, 25(1), 69-89. https:/ / doi.org/10.1080/13540602.2018.1527762

Lestari, L., \& Fauzi, A. (2019). The analysis of student prior knowledge to flood disaster. Journal of Physics: Conference Series, 1185, 012073. https://doi.org/ 10.1088/1742-6596/1185/1/012073

Losano, L., Fiorentini, D., \& Villarreal, M. (2018). The development of a mathematics teacher's professional identity during her first year teaching. Journal of Mathematics Teacher Education, 21(3), 287 315. https:/ / doi.org/10.1007/s10857-017-9364-4

Luft, J. (2007). Minding the gap: Needed research on beginning/newly qualified science teachers. Journal of Research in Science Teaching, 44(4), 532-537. https:/ / doi.org/10.1002/tea.20190

Luft, J. A., \& Patterson, N. C. (2002). Bridging the gap: Supporting beginning science teachers. Journal of Science Teacher Education, 13(4), 267-282. https:/ / doi.org/10.1023/A:1022518815872

Lutovac, S., \& Kaasila, R. (2018). Future directions in research on mathematics-related teacher identity. International Journal of Science and Mathematics
Education, 16(4), 759-776. https:/ / doi.org/10.1007/ s10763-017-9796-4

Maddamsetti, J. (2020). Where all the good teachers are cape verdean Americans: A white teacher's identity positionings in an urban elementary school. The Urban Review, 52, 100-126. https://doi.org/ 10.1007/ s11256-019-00514-5

Mahmoudi-Gahrouei, V., Tavakoli, M., \& Hamman, D. (2016). Understanding what is possible across a career: Professional identity development beyond transition to teaching. Asia Pacific Education Review, 17(4), 581-597. https://doi.org/10.1007/s12564016-9457-2

Mambu, J. E. (2017). Unraveling relatively unclear stories: A narrative analysis of student-teachers' identity work. Indonesian Journal of Applied Linguistics, 6(2), 172. https://doi.org/10.17509/ ijal.v6i2.4842

Manara, C. (2013). English language educators' professional learning as a site of identity struggle. Pertanika J. Soc. Sci. E Hum, 21(3), 1193-1212.

Mansour, N. (2013). Consistencies and inconsistencies between science teachers' beliefs and practices. International Journal of Science Education, 35(7), 12301275. https://doi.org/10.1080/09500693.2012. 743196

Marco-Bujosa, L., Levy, A. J., \& McNeill, K. (2018). A case study exploring the identity of an in-service elementary science teacher: A language teacher first. Research in Science Education, 50, 79-98. https:/ / doi.org/10.1007/s11165-017-9681-8

Martin, J. (2019). Researching primary teachers' professional agency: Employing interactive ethnography to overcome reluctance to teach science. Research in Science Education, 49(5), 1279 1299. https:/ / doi.org/10.1007/s11165-017-9654-y

McCroskey, J. C., Richmond, V. P., \& Bennett, V. E. (2006). The relationships of student end-of-class motivation with teacher communication behaviors and instructional outcomes. Communication Education, 55(4), 403-414. https: / / doi.org/10.1080/ 03634520600702562

Merriam, S. B., \& Tisdell, E. J. (2015). Qualitative research: A guide to design and implementation (Fourth edition). John Wiley \& Sons.

Moreau, M.-P., \& Brownhill, S. (2017). Teachers and educational policies: Negotiating discourses of male role modelling. Teaching and Teacher Education, 67, 370-377. https:/ / doi.org/10.1016/j.tate.2017.07. 001

Naidoo, K. (2017). Capturing the transformation and dynamic nature of an elementary teacher candidate's identity development as a teacher of science. Research in Science Education, 47(6), 13311355. https:/ / doi.org/10.1007/s11165-016-9550-x 
Ro, J. (2019). Seeking the meaning of the job: Korean novice secondary teachers' professional identity. Asia Pacific Education Review, 20(1), 135-146. https: / / doi.org/10.1007/s12564-018-9573-2

Schaefer, L. (2013). Beginning teacher attrition: A question of identity making and identity shifting. Teachers and Teaching, 19(3), 260-274. https: / / doi.org/10.1080/13540602.2012.754159

Settlage, J., Southerland, S. A., Smith, L. K., \& Ceglie, R. (2009). Constructing a doubt-free teaching self: Selfefficacy, teacher identity, and science instruction within diverse settings. Journal of Research in Science Teaching, 46(1), 102-125. https://doi.org/10.1002/ tea. 20268

Tangen, D., Henderson, D., Alford, J., Hepple, E., Alwi, A., Abu Hassan Shaari, Z., \& Alwi, A. (2017). Shaping global teacher identity in a short-term mobility programme. Asia-Pacific Journal of Teacher Education, 45(1), 23-38. https://doi.org/10.1080/ 1359866X.2015.1119803

Teng, (Mark) Feng. (2019). Understanding teacher autonomy, teacher agency, and teacher identity: Voices from four EFL student teachers. English Teaching $\mathcal{E} \quad$ Learning, 43(2), 189-212. https://doi.org/10.1007/s42321-019-00024-3

Trent, J. (2012). Becoming a teacher: The identity construction experiences of beginning English language teachers in Hong Kong. The Australian Educational Researcher, 39(3), 363-383. https: / / doi.org/10.1007/s13384-012-0067-7

Trent, J. (2016). Constructing professional identities in shadow education: Perspectives of private supplementary educators in Hong Kong. Educational Research for Policy and Practice, 15(2), 115-130. https://doi.org/10.1007/s10671-0159182-3

van Lankveld, T., Schoonenboom, J., Kusurkar, R., Beishuizen, J., Croiset, G., \& Volman, M. (2016). Informal teacher communities enhancing the professional development of medical teachers: A qualitative study. BMC Medical Education, 16(1), 109. https:/ / doi.org/10.1186/s12909-016-0632-2
Wang, L., \& Du, X. (2014). Chinese teachers' professional identity and beliefs about the teacher-student relationships in an intercultural context. Frontiers of Education in China, 9(3), 429-455. https://doi.org/ 10.1007/BF03397030

Wei, B., Avraamidou, L., \& Chen, N. (2019). How a beginning science teacher deals with practical work: An explorative study through the lens of identity. Research in Science Education. https:/ / doi.org/10.1007/s11165-019-9826-z

Widodo, H. P. (2017). Constructing and negotiating agency and identity of english language learners: Teacher-learner driven ESP materials development in the Indonesian secondary school context. Electronic Journal of Foreign Language Teaching, 14(2), 233-249.

Wirza, Y. (2018). A narrative case study of Indonesian EFL learners' identities. Indonesian Journal of Applied Linguistics, 8(2), 473-481. https:/ / doi.org/10.17509 /ijal.v8i2.13313

Wulff, P., Hazari, Z., Petersen, S., \& Neumann, K. (2018). Engaging young women in physics: An intervention to support young women's physics identity development. Physical Review Physics Education Research, 14(2), 020113. https:/ / doi.org/ 10.1103/PhysRevPhysEducRes.14.020113

Ye, J., \& Zhao, D. (2019). Developing different identity trajectories: Lessons from the Chinese teachers. Teachers and Teaching, 25(1), 34-53. https://doi.org/10.1080/13540602.2018.1532408

Zhang, Q., Clarke, A., \& Lee, J. C. K. (2018). Pre-service teachers' professional identity development within the context of school-based learning to teach: An exploratory study in China. The Asia-Pacific Education Researcher, 27(6), 477-486. https:/ / doi.org/10.1007/s40299-018-0408-z

Zhao, H., \& Zhang, X. (2017). The influence of field teaching practice on pre-service teachers' professional identity: A mixed methods study. Frontiers in Psychology, 8, 1264. https:/ / doi.org/10.3389/fpsyg.2017.01264

\section{http://www.ejmste.com}

